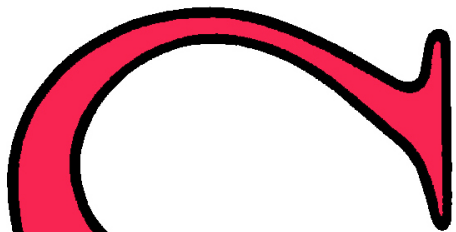

DECEM B E R 1963

VOLUME XXII，NUMBER 4
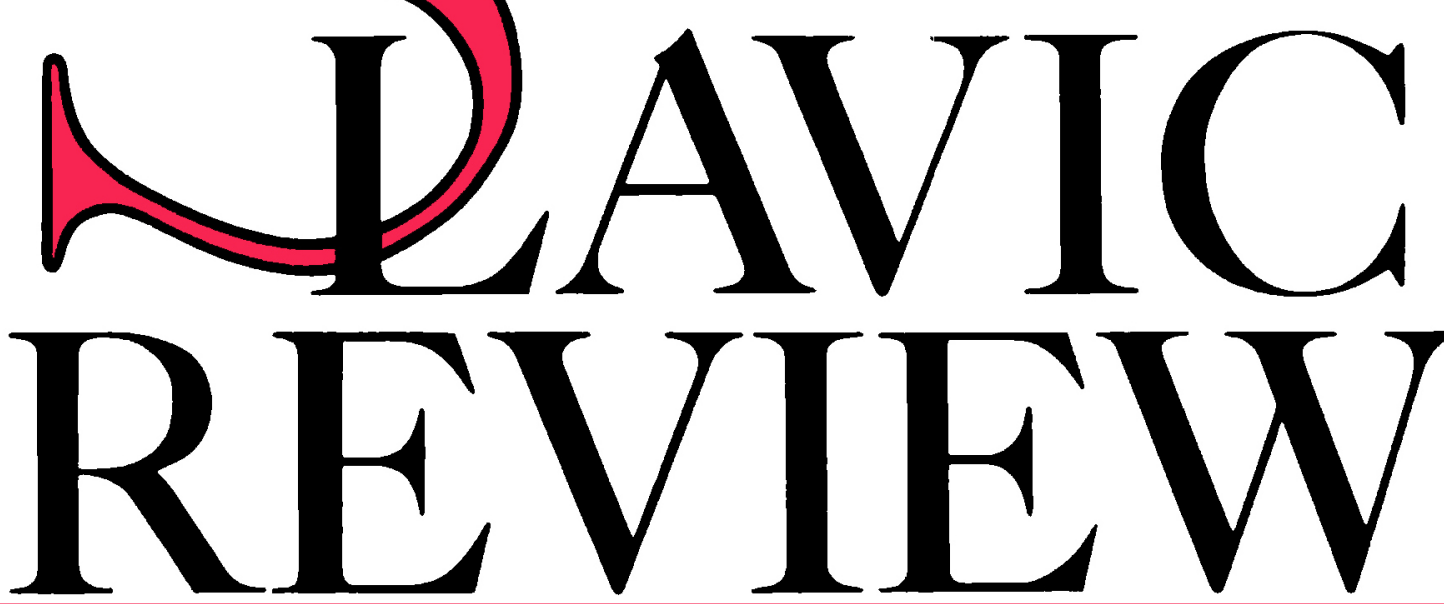

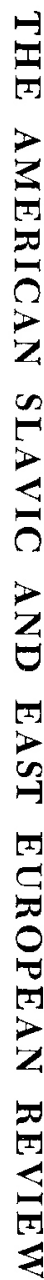

American Quarterly of Soviet and East European Studies

DIS C U S I I N

Karl A. Wittfogel: Russia and the East: A Comparison and Contrast

Comments by Nicholas V. Riasanovsky and Bertold Spuler

A RT T CLES

Thomas Riha: Riech': A Portrait of a Russian Newspaper

Murray Yanowitch: The Soviet Income Revolution

Peter Brock: Leon Rzewuski and the Village Commune

Oles M. Smolansky: Moscow-Cairo Crisis, 1959

NOTESAND COMMENT

Andreas Tietze: The Use of Spoken Russian in

Azerbaijani Literature

Alfred Zauberman: Liberman's Rules of the Game for Soviet Industry

REVIEW ARTICLE

Hugh McLean: A Contribution to the Revival of Leskov 
HONORARY EDITORS

Harold H. Fisher

Geroid T. Robinson
Oscar Halegki

ERNEST J. Simmons
WACLAW LEDNICKI

George Vernadsky

\author{
EDITORIAL BOARD
}

\section{William B. Edgerton Gregory Grossman Indiana University \\ Ghauncy D. HaRris \\ University of Chicago \\ Marshall D. Shulman \\ Fletcher School of Law and Diplomacy}

MANAGING EDITOR

Donald W. Treadgold

University of Washington

ASSISTANT EDITOR: GLADYS GREENWOOD

editorial assistant: Leila Charbonneau

\author{
NEWS OF THE PROFESSION EDITOR \\ RALPh T. Fisher, JR. \\ University of Illinois
}

The Editors assume no responsibility for statements of fact or opinion made by contributors.

The SLAVIC REVIEW is published quarterly, in March, June, September, and December, by the American Association for the Advancement of Slavic Studies, Inc., and is sent to all Association members. Members also receive an annual American Bibliography of Russian and East European Studies and a biannual Newsletter. Applications for membership are accepted by the Secretary of the Association, Professor Ralph T. Fisher, 112 Davenport House, 620 E. Daniel St., Champaign, Illinois, from individuals having professional engagement in the field. Nonmembers also may place subscriptions with Professor Fisher. Subscriptions, without membership, are $\$ 10.00$ a year, foreign and domestic postage included. Single numbers are $\$ 2.75$. Entered as second-class matter at the Post Office at Seattle, Washington.

Articles submitted and books for review, as well as all correspondence concerning editorial matters, should be addressed to Professor Donald W. Treadgold, 508 Thomson Hall, University of Washington, Seattle 5 . Items for the "News of the Profession" section and all communications regarding membership and subscriptions should be sent to Professor Fisher in Champaign.

Copyright (C) 1963 by The American Association for the Advancement of Slavic Studies, Inc.
EDITORIAL COMMITTEE

Frederick C. BarGHoorN Yale University

Abram Bergson Haruard University

Gyrix E. Black Princeton University

DEMING BRown University of Michigan

ROBERT F. BYRNES Indiana University

JoHn S. CuRTiss Duke University

Victor ERLICH Yale University

Merle Fainsod Harvard University

AleXander Gerschenkron Harvard University

AleX INkeles Harvard University

Charles Jelavich Indiana University

Anatole G. Mazour Stanford University

Philip E. Mosely Columbia University

Oliver H. Radkey U*iversity of Texas

Henry L. Roberts Columbia University

Alfred SenN University of Pennsylvania

Demitri B. SHImkin University of Illinois

Gleb Struve University of California

S. Harrison Thomson University of Colorado

Julian Towster University of California

RENE WELLEK Yale University

Francis J. Whitfield University of California 


\title{
CONTENTS OF VOLUME XX
}

DISCUSSION

\author{
Number 1, March 1963
}

Peter F. Sugar: The Nature of the Non-Germanic Societies

Habsburg Rule . . . . . . . . . . . . . . . . . . 1

Stephen Fischer-Galati: Nationalism and Kaisertreue . . . . . . 31

Hans Kohn: The Viability of the Habsburg Monarchy . . . . . 37

Peter F. Sugar: Reply . . . . . . . . . . . . . . . . . 43

ARTICLES

Paul H. Avrich: The Bolshevik Revolution and Workers' Control in

Russian Industry . . . . . . . . . . . . . . . . . . . 47

Paul Shoup: Yugoslavia's National Minorities under Communism . 64

Bernice Madison: Russia's Illegitimate Children Before and After

the Revolution . . . . . . . . . . . . . . . . . . 82

Bertram D. Wolfe: Lenin and Inessa Armand . . . . . . . . . 96

NOTES AND COMMENT

D. S. Likhachev: Further Remarks on the Problem of Old Russian

Culture . . . . . . . . . . . . . . . . . . . . 115

Janis Labsvirs: The Effect of Collectivization on Latvian

Agriculture

REVIEW ARTICLE

F. D. Reeve: Recent Soviet Studies in Russian Classical Literature . 126

Reviews . . . . . . . . . . . . . . . . . . . . . 135

LETTERS . . . . . . . . . . . . . . . . . . . . . . . . . . . . 188

News of the Profession . . . . . . . . . . . . . . . . . . . . . . . 191

BOOKS RECEIVED . . . . . . . . . . . . . . . . . . . 195

DISCUSSION

Number 2, June 1963

Ivan L. Rudnytsky: The Role of the Ukraine in Modern History . . 199

Arthur E. Adams: The Awakening of the Ukraine . . . . . . . 217

Omeljan Pritsak and John S. Reshetar, Jr.: The Ukraine and the Dialectics of Nation-Building . . . . . . . . . . . . . 224

Ivan L. Rudnytsky: Reply . . . . . . . . . . . . . . . 256

ARTICLES

Jonathan Frankel: Economism: A Heresy Exploited . . . . . . 263

George Barany: The Hungarian Diet of $1839-40$ and the Fate of Szechenyi's Middle Course . . . . . . . . . . . . . . 285

NOTES AND COMMENT

D. M. Corbett: The Rehabilitation of Mykola Skrypnyk . . . . . 304

Harold J. Berman: The Struggle of Soviet Jurists against a Return to Stalinist Terror . . . . . . . . . . . . . . . . . 314

REVIEW ARTICLE

Paul J. Friedrich: Some Recent Works on Communism and Christianity

ReVIEWS . . . . . . . . . . . . . . . . . . . . . . 329

LETTERS . . . . . . . . . . . . . . . . . . . . 393

News of the Profession . . . . . . . . . . . . . . . . . . . . 397

BoOKS ReGEIVED . . . . . . . . . . . . . . . . . . . 399

A List of Current Paperbound Books in the Slavic Field . . . . 403 
Oswald P. Backus III: The Problem of Unity in the Polish-

Lithuanian State . . . . . . . . . . . . . . . . 411

Oscar Halecki: Why Was Poland Partitioned? . . . . . . . . . . 432

Joseph Jakstas: How Firm Was the Polish-Lithuanian Federation? . 442

Oswald P. Backus III: Reply . . . . . . . . . . . . . . . 450

\section{ARTICLES}

James Allen Rogers: The Russian Populists' Response to Darwin . . 456

Donald Fanger: Dostoevsky's Early Feuilletons: Approaches to a

Myth of the City . . . . . . . . . . . . . . . . . 469

Paul M. Cocks: The Purge of Marshal Zhukov . . . . . . . . . . 483

V. Stanley Vardys: The Partisan Movement in Postwar Lithuania . . 499

\section{NOTES AND COMMENT}

E. Joe DeMaris: Lenin and the Soviet "Control by the Ruble" System 523

George D. Jackson, Jr.: Western Studies of International Socialism

as Seen by a Soviet Historian . . . . . . . . . . . . 530

\section{REVIEW ARTICLE}

Chester S. Chard: Soviet Scholarship on the Prehistory of Asiatic

Russia

ReVIEWS . . . . . . . . . . . . . . . . . . . . . . 547

LETTERS . . . . . . . . . . . . . . . . . . . . . . 615

News of THE Profession . . . . . . . . . . . . . . . . . 620

BOOKS ReCEIVED . . . . . . . . . . . . . . . . . . . 624

\section{DISCUSSION}

Number 4, December 1963

Karl A. Wittfogel: Russia and the East: A Comparison and Contrast 627

Nicholas V. Riasanovsky: "Oriental Despotism" and Russia . . . . 644

Bertold Spuler: Russia and Islam . . . . . . . . . . . . . 650

Karl A. Wittfogel: Reply . . . . . . . . . . . . . . . . 656

ARTICLES

Thomas Riha: Riech': A Portrait of a Russian Newspaper . . . . 663

Murray Yanowitch: The Soviet Income Revolution . . . . . . . 683

Peter Brock: Leon Rzewuski and the Village Commune . . . . . 698

Oles M. Smolansky: Moscow-Gairo Crisis, 1959 . . . . . . . . 713

NOTES AND COMMENT

Andreas Tietze: The Use of Spoken Russian in Azerbaijani

Literature . . . . . . . . . . . . . . . . . . . . 727

Alfred Zauberman: Liberman's Rules of the Game for Soviet Industry 734

REVIEW ARTICLE

Hugh McLean: A Contribution to the Revival of Leskov . . . . . 745

Reviews . . . . . . . . . . . . . . . . . 751

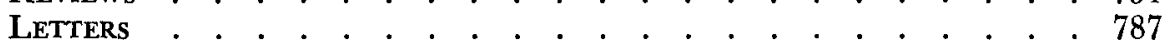

News of the Profession . . . . . . . . . . . . . . . . . . . . . . . .7789

BOOKS RECEIVED . . . . . . . . . . . . . . . . . . . . . 793

INDEX TO VOLUMe XXII 